
нические и морфологические особенности у детей и подростков

Пастернак И.А. ${ }^{1}$, Казачков Е.Л. ${ }^{1}$, Пастернак А.Е. ${ }^{2}$

${ }^{1}$ ФБОУ ВО «Южно-Уральский государственный медицинский университет» Минздрава России (Челябинск)

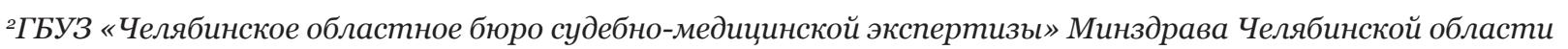

\title{
Follicular-cell tumors of the thyroid gland: clinicall and morpholog- ical characteristics in children and adolescents
}

\author{
Pasternak I.A. ${ }^{1}$, Kazachkov E.L. ${ }^{1}$, Pasternak A.E. ${ }^{2}$ \\ ${ }^{1}$ South Ural State Medical University (Chelyabinsk) \\ ${ }^{2}$ Chelyabinsk Regional Bureau of Forensic Medical Examination
}

\begin{abstract}
АННОТАЦИЯ
Исследовали операционно-биопсийный материал опухолей щитовидной железы 55 детей и подростков 8-17 лет. С учетом новой классификации опухолей $(\mathrm{BO3}, 2017)$ у 21 чел. были верифицированы опухоли фоллику-

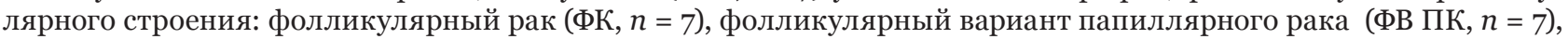
фолликулярная аденома (ФА, $n=4)$, неинвазивная фолликулярная опухоль с ядрами папиллярного типа (НФО, $n=2)$, фолликулярная опухоль неопределенного злокачественного потенциала $(n=1)$. Проведенное исследование свидетельствует о невысокой частоте у детей и подростков неинвазивной фолликулярной опухоли с ядрами папиллярного типа -4 \% случаев. Особенностями доброкачественных и злокачественных опухолей с ядрами папиллярного типа являются: сглаживание половых различий, частое сочетание с аутоиммунными заболеваниями щитовидной железы, увеличение кариометрических параметров по сравнению с фолликулярными аденомами и карциномами. Ультраструктурный анализ показал, что клетки опухолей с ядрами папиллярного типа (ФВ ПК и НФО) отличаются выраженным полиморфизмом. Вместе с тем в НФО с ядрами папиллярного типа превалируют клетки с признаками нейроэндокринной дифференцировки в отличие от ФВ ПК, при котором преобладают клеточные формы с утратой секреторной активности и органоспецифичности.
\end{abstract}

Ключевъе слова: фолликулярно-клеточные опухоли, опухоли фолликулярного строения, карцинома щитовидной железы, морфология, дети и подростки.

\begin{abstract}
Operational bioptic material of thyroid gland tumors taken from 55 children and adolescents 8-17 years old was investigated. Taking into account the new classification of tumors (WHO, 2017), tumors of the follicular structure were verified in 21 patients: follicular cancer (FC, $n=7$ ), follicular variant of papillary cancer (FV PC, $n=7$ ), follicular adenoma (FA, $n=4$ ), noninvasive follicular thyroid neoplasm with nuclei of papillary type (NFT, $n=2$ ), follicular thyroid tumor of uncertain malignant potential $(n=1)$. The conducted study indicates a low incidence of noninvasive follicular thyroid neoplasm with nuclei of papillary type in children and adolescents $-4 \%$ of cases. The peculiarities of benign and malignant tumors with nuclei of papillary type are the following: smoothing of sexual differences, frequently combined with autoimmune diseases of the thyroid gland, the increase of karyometric parameters as compared with follicular adenomas and carcinomas. Ultrastructural analysis showed that the tumor cells with nuclei of papillary type (FV PC, NFT) distinguish themselves by expressed polymorphism. At the same time, cells with signs of neuroendocrine differentiation prevail in a NFT neoplasm with nuclei of papillary type in contrast to FV PC, in which cellular forms with the loss of secretory activity and organospecificity predominate.
\end{abstract}

Keywords: follicular cell tumors, tumors of follicular structure, thyroid cancer, morphology, children and adolescents.

Поступила 26.02.2019

Принята 28.03.2019

*Автор, ответственный за переписку

Пастернак Илона Анатольевна: ФГБОУ ВО «Южно-Уральский государственный медицинский университет» Минздрава России. 454092, г. Челябинск, ул. Воровского, 64.

E-mail: pasternak.ilona@mail.ru
Received 26.02.2019

Accepted 28.03.2019

*Corresponding author

Pasternak Ilona Anatolyevna: South Ural State Medical University, 64, Vorovskogo Str., Chelyabinsk, 454092, Russia.

E-mail: pasternak.ilona@mail.ru 


\section{ВВЕДЕНИЕ}

Дифференциальная диагностика доброкачественных, злокачественных опухолей и гиперпластических процессов в щитовидной железе вызывает значительные трудности в патологоанатомической практике $[1,2]$. При этом в литературе дискутируются вопросы терминологии патологических процессов в щитовидной железе, а также диагностической ценности некоторых структурных критериев тиреоидных неоплазм. Наличие папиллярных структур, псаммомных телец, плоскоклеточной метаплазии, клеточного и ядерного полиморфизма тиреоидного эпителия, склероза и гиалиноза стромы не специфично и обнаруживается при опухолевом росте, гиперпластических, воспалительных и аутоиммунных заболеваниях щитовидной железы [1-3].

Самой распространенной злокачественной опухолью щитовидной железы у детей и подростков является папиллярный рак, характеризующийся клинико-эпидемиологическими и морфологическими отличиями от одноимённой опухоли взрослых [1, 2, 4-6]. Заболеваемость папиллярным раком в детской популяции РФ, проживающей на территориях, загрязненных радионуклидами после Чернобыльской аварии, достоверно возросла $[7,8]$. Принято считать, что такой «техногенный» рак обладает более агрессивным биологическим «поведением»: частым мультицентрическим и инфильтрирующим ростом опухоли, обширным метастазированием, рецидивами после хирургического лечения $[5,8]$. При этом латентный период карциномы короче, чем у взрослых, а половые различия минимальны [8, 9]. Рак щитовидной железы в детском возрасте характеризуется особыми гистологическими вариантами, отсутствием анапластических карцином и мутаций гена BRAF ${ }^{\mathrm{V} 60 о \mathrm{E}}$, выявляемых при папиллярном раке у взрослого населения $[1,2,4]$. Кроме того, папиллярные карциномы у детей характеризуются преобладанием солидного строения, уменьшением числа внутриядерных бороздок и экспрессии тиреоглобулина в опухолевых клетках [5].

В последнем пересмотре гистологической классификации опухолей щитовидной железы (2017) были выделены новые категории тиреоидной патологии - «неинвазивная фолликулярная опухоль с ядрами папиллярного типа», ранее относящаяся к фолликулярному варианту папиллярной карциномы, а также некоторые иные гистологические формы фолликулярноклеточного рака $[2,10]$. Этот пересмотр стал результатом междисциплинарного ретроспектив-

\section{INTRO D UCTION}

Differential diagnostics of benign and malignant tumors, and hyperplastic processes in the thyroid gland is a considerable challenge in pathoanatomical practice $[1,2]$. At the same time the issues on pathologic processes terminology as well as those of diagnostic value of certain structural criteria of thyroid neoplasms are being discussed in the publications. The presence of papillary structures, psamommal corpuscles, planocellular metaplasias, cellular and nuclear polymorphism of thyroid epithelium, sclerosis and stroma hyalinosisis nonspecifically and is revealed in tumor growth, hyperplastic, inflammatory and autoimmune diseases of the thyroid gland [1-3].

The most widespread thyroid tumor in children and adolescents is papillary carcinoma characterized by clinicoepidemiological and morphological differences from the tumor of the same name in adults $[1,2,4-6]$. Papillary carcinoma morbidity rate among children's population of the Russian Federation residing on the territories polluted by radionuclides after the Chernobyl disaster has increased reliably [7, 8]. Broadly speaking such "technogenic" carcinoma has more aggressive biological "behavior": frequent multicentric and infiltrating tumor growth, extensive metastasis, recurrences after surgery $[5,8]$. At that the carcinoma latent period is shorter than in adults, and sexual differences are minimum [8, 9]. Thyroid carcinoma in childhood is characterized by the specific histological variations, the absence of anaplastic carcinomas BRAF ${ }^{\mathrm{V} 600 \mathrm{E}}$ gene mutations, revealed in papillary carcinoma in adults $[1,2,4]$. Besides papillary carcinomas in children are characterized by the predominance of solid structure, intranuclear groove decrease number and expression of thyreoglobulin in tumor cells [5].

In last revision of histological classification of thyroid tumors (2017) new categories of thyroid pathology were detailed - "noninvasive follicular thyroid neoplasm with nuclei of papillary type" earlier referred to follicular variant of papillary carcinoma before as well as certain other histological forms of follicular cell carcinoma $[2,10]$. This revision was the result of interdisciplinary retrospective consensus on thyroid tumors on the basis of their genetic profile identification [11]. Such approach has shown that the incidence of noninvasive follicular thyroid neoplasm with nuclei of papillary type amounts to $16-23 \%$ of all the papillary carcinomas among adults [12]. At the same time over last 30 years the 
ного консенсуса по опухолям щитовидной железы на основе идентификации их генетического профиля [11]. Такой подход показал, что среди взрослых пациентов частота неинвазивной фолликулярной опухоли с ядрами папиллярного типа достигает 16-23 \% от всех папиллярных карцином [12]. Вместе с тем за последние 30 лет рост заболеваемости раком щитовидной железы отмечается не только среди взрослого населения. Так, за этот временной период у детей Челябинской области частота карцином этого органа увеличилась в 6 раз $[6,13,14]$.

\section{ПЕЛЬ ИССЛЕЛОВАНИЯ}

Анализ клинико-морфологических особенностей опухолей щитовидной железы фолликулярного строения у детей с учетом нового классификационного подхода.

\section{МАТЕРИАЛЫ И МЕТОДЫ}

Пересмотру и новой градации с учетом положений классификации ВОЗ (2017) [10] подвергался операционно-биопсийный материал опухолей щитовидной железы 55 детей и подростков в возрасте 8-17 лет, оперированных в Центре хирургической эндокринологии г. Челябинска в 20002018 гг. Исследование включало анализ данных медицинской документации.

Кусочки опухолевой ткани фиксировали в 10\% забуференном формалине с последующим приготовлением парафиновых блоков. Серийные тканевые срезы окрашивали гематоксилином и эозином.

Морфометрическое изучение опухолей фолликулярного строения проводилось с применением лицензионной программы анализа изображения микрообъектов «ВидеоТесТ-Морфология 5.1» («ВидеоТесТ», Россия).

Для электронной микроскопии кусочки опухоли фиксировали в 2\% параформальдегиде и 2.5\% глутаровом альдегиде на какодилатном буфере (по Карновскому) с 5\% сахарозой и в $2 \%$ тетраоксиде осмия, затем контрастировали ацетатом урана, заливали в смолу. Ультратонкие срезы толщиной 60 нм контрастировали по методу Рейнольдса уранилацетатом и цитратом свинца. Препараты изучали в сканирующем электронном микроскопе AURIGA FIB-SEM workstation (Carl Zeiss \& MT, Германия) со STEM-детектором в диапазоне увеличения 1200-12 430.

Статистическую обработку полученных данных осуществляли с помощью лицензионного пакета прикладных программ Statistica 6.0 (StatSoft, Inc.). Статистическая значимость раз- carcinoma incidence rate is noted not only in the adult population. So over this period of time the six fold carcinoma rate of this organ is registered in children in the Chelyabinsk Region $[6,13,14]$.

\section{AIM OF THE RESEARCH}

The analysis of clinicomorphological characteristics of thyroid tumors of follicular structure in children and adolescents in terms of new classification approach.

\section{MATERIALS AND METHODS}

Operational bioptic material of thyroid tumors taken from 55 children and adolescents 8-17 years old, operated in the Center of Surgical Endocrinology, Chelyabinsk in 2000-2018, was reconsidered and regraded taking into account WHO new classification (2017) [10]. The study included the analysis of medical records.

Small pieces of tumor tissue was fixed in $10 \%$ buffered formalin with the following preparation of paraffin unites. Serial tissue sections were stained with hematoxylin and eosine.

Morphometric investigation of tumors of the follicular structure was performed with application of licensed program of microobject image analysis "VideoTesT-Morphologia 5.1" (VideoTesT, Russia).

For electronic microscopy the tumors were fixed in $2 \%$ paraformaldehyde and $2.5 \%$ glutaric aldehyde at cacodylate buffer (by Karnofsky scale) with 5\% sucrose and in $2 \%$ osmium tetroxide, then were contrasted with uranium acetate, and coated with resin. Ultrathin sections as thick as $60 \mathrm{~nm}$ were contrasted using Reynolds staining by uranyl acetate and lead citrate. Preparations were investigated under the scanning electronic microscope AURIGA FIBSEM workstation (Carl Zeiss \& MT, Germany) with STEM-detector at the zoom range of 1200-12 430 .

Statistical treatment of the findings was done by means of licensed applied program package STATISTICA 6.o ("StatSoft", Inc.). Statistical significance of differences of the compared quantitative attributes was estimated by nonparametric statistics: Mann Whitney U-test was done. Qualitative signs were compared with exact Fisher's test calculation.

The study conduction was approved by the local ethical committee.

\section{RESULTS AND DISCUSSION}

50 cases of follicular cell tumors were diagnosed among thyroid neoplasms. There were papillary (72\%) and follicular carcinomas (14\%), follicu- 
личий сравниваемых количественных признаков оценивалась методом непараметрической статистики: проводился $U$-тест Манна - Уитни. Качественные признаки сравнивались с вычислением точного критерия Фишера.

Проведение исследований одобрено локальным этическим комитетом.

\section{РЕЗУЛЬТАТЫ И ОБСУЯКДЕНИЕ}

Среди новообразований щитовидной железы было диагностировано 50 случаев фолликулярно-клеточных опухолей. Они были представлены папиллярной (72 \%) и фолликулярной карциномой (14 \%), фолликулярной аденомой (8 \%), неинвазивной фолликулярной опухолью с ядрами папиллярного типа (4 \%), фолликулярной опухолью неопределенного злокачественного потенциала (2 \%). В 21 случае были верифицированы опухоли фолликулярного строения [10]: фолликулярный вариант папиллярной карциномы (ФВ ПК) - 7 наблюдений, фолликулярная карцинома (ФК) - 7 наблюдений, фолликулярная аденома (ФА) - 4 наблюдения, неинвазивная фолликулярная опухоль с ядрами папиллярного типа (НФО) - 2 наблюдения, фолликулярная опухоль неопределенного злокачественного потенциала - 1 наблюдение (табл. 1).

На момент операции возраст детей и подростков с карциномами был меньшим, чем у пациентов с доброкачественными новообразованиями фолликулярного строения. При этом статистически значимых различий в возрасте и размерах доброкачественных и злокачественных новообразований в исследуемой группе не установлено. Карциномы (ФВ ПК и ФК) характеризовались наличием солитарного узла (в единичном случае - многофокусный рост) с инвазией в капсулу (окружающую ткань) и отсутствием метастазирования. В качестве коморбидного заболевания при ФВ ПК и НФО был диагностирован аутоиммунный тиреоидит в отличие от преобладания нетоксического узлового зоба при ФК и ФА.

Кариометрический анализ показал, что максимальные значения площади, периметра и размеров ядер были при ФВ ПК. Наименышие показатели периметра и размера ядра были установлены при ФА. При этом площадь ядер при фолликулярной карциноме и аденоме не отличалась. Анализом, проведенным нами на небольшом числе наблюдений, установлено, что опухоли с ядрами папиллярного типа (ФВ ПК, НФО) обладают своеобразием клинико-морфологических проявлений (половое соотношение пациентов, сочетание с аутоиммунным тиреоидитом, укрупнение lar adenoma (8\%), noninvasive follicular thyroid neoplasm with nuclei of papillary type (4\%), follicular thyroid tumor of uncertain malignant potential (2\%). Tumors of follicular structure were verified in 21 cases [10]: follicular variant of papillary cancer (FV PC) - 7 cases, follicular cancer (FC) - 7 cases, follicular adenoma (FA) -4 cases, noninvasive follicular thyroid neoplasm with nuclei of papillary type (NFT) - 2 cases, follicular thyroid tumor of uncertain malignant potential - 1 case (Table 1 ).

At the date of the surgery children and adolescents with carcinomas were younger than the affected children with benign neoplasm of follicular structure. At the same time statistical significant differences in the age, and benign and malignant neoplasm size were not observed in the studied group. Carcinomas (FV PC, NFT) were characterized by the presence of solitary node (in the single case - multifocal growth) with the invasion into the capsule (surrounding the tissue) and the absence of metastasis. Autoimmune thyroiditis was diagnosed as a comorbid disease in FV PC and NFT unlike the prevalence of nontoxic nodular goiter in FC and FA.

Karyometric analysis revealed that maxima of area, perimeter and nucleus size were in FV PC. The smallest values of perimeter and nucleus size were established in FA. At that, nucleus area differed in neither follicular carcinoma nor follicular adenoma. While analyzing the small number of cases we determined that neoplasms with nuclei of papillary type (FV PC, NFT) possess the peculiarity of clinicomorphological manifestations (patients' sexual ratio, combination with autoimmune thyroiditis, nucleus enlargement). Low NFT incidence in our study is commensurable with the results of revision of thyroid neoplasms in the pediatric age performed in healthcare centers in Europe and USA [15].

While investigating under the electron microscopy FV PC cells were characterized by the loss of intercellular contacts and desmosomes, the absence of polarity and microvilli in the apical area. The nuclei looked large with condensed heterochromatin along the edges of karyolemma, more often the nucleus was single, at times the denuclearized cells were revealed. Nucleocytoplasmic invaginations were identified in certain tumor cells (Fig. 1, A). Cytoplasm was poor, vacuolated with the reduction of granular endoplasmic reticulum and poorly developed laminar complex (Fig. 1, B). Such changes point to the high proliferative activity as well as the loss of specific ultrastructural signs of the neuroendocrinal cells. The signs of destruction with the 
Таблица 1. Характеристика опухолей щитовидной железы фолликулярного строения у детей и подростков Table 1. Characteristics of thyroid tumors of follicular structure in children and adolescents

\begin{tabular}{|c|c|c|c|c|}
\hline Показатель / Indicator & $\begin{array}{l}\text { ФВ ПК }(n=7) \\
\operatorname{FV~PC~}(n=7)\end{array}$ & $\begin{array}{l}\Phi K(n=7) \\
\operatorname{FC~}(n=7)\end{array}$ & $\begin{array}{l}\Phi A(n=4) \\
\text { FA }(n=4)\end{array}$ & $\begin{array}{l}\operatorname{HФO}(n=2) \\
\operatorname{NFT}(n=2)\end{array}$ \\
\hline Возраст, лет / Age, years & $14.1 \pm 0.9$ & $14.1 \pm 0.8$ & $16.5 \pm 0.5$ & $16.0 \pm 1.0$ \\
\hline Пол, ж : м / Gender, F : M & $1.3: 1$ & $6: 1$ & $4: 0$ & $1: 1$ \\
\hline $\begin{array}{l}\text { Размеры опухоли, мм } \\
\text { Tumor size, mm }\end{array}$ & $16.42 \pm 3.7$ & $19.0 \pm 3.3$ & $17.8 \pm 5.1$ & $20.0 \pm 5$ \\
\hline $\begin{array}{l}\text { Инкапсулированный рост, абс. } \\
\text { Encapsulated growth, abs. }\end{array}$ & 6 & 6 & 4 & 2 \\
\hline $\begin{array}{l}\text { Мультифокальный рост, абс. } \\
\text { Multifocal growth, abs. }\end{array}$ & 1 & - & - & - \\
\hline $\begin{array}{l}\text { Инфильтрирующий рост, абс. } \\
\text { Infiltrating growth, abs. }\end{array}$ & 7 & $\begin{array}{l}\text { Широко инвазивный }-6 \\
\text { Widely invasive }-6\end{array}$ & - & - \\
\hline \multicolumn{5}{|l|}{ Стадия pTNM, абс. / pTNM stage, abs.: } \\
\hline $\mathrm{T} 1$ & 4 & 3 & - & - \\
\hline $\mathrm{T} 2$ & $\begin{array}{l}4 \\
3\end{array}$ & 4 & - & - \\
\hline NoMo & 7 & 7 & - & - \\
\hline $\begin{array}{l}\text { Аутоиммунный тиреоидит, абс. } \\
\text { Autoimmune thyroiditis, abs. }\end{array}$ & 3 & - & - & 1 \\
\hline $\begin{array}{l}\text { Нетоксический узловой зоб, абс. } \\
\text { Nontoxic nodular goiter, abs. }\end{array}$ & 1 & - & - & - \\
\hline $\begin{array}{l}\text { Диффузный токсический зоб, абс. } \\
\text { Diffuse toxic goiter, abs. }\end{array}$ & 1 & 3 & 1 & - \\
\hline $\begin{array}{l}\text { Площадь ядер, мкм } \\
\text { Nucleus area, } \mu \mathrm{m}\end{array}$ & $59.9 \pm 0.6^{*}$ & $28.0 \pm 1.0^{*}$ & $22.5 \pm 0.5$ & $30.7 \pm 0.6^{*}$ \\
\hline $\begin{array}{l}\text { Периметр ядер, мкм } \\
\text { Nucleus perimeter, } \mu \mathrm{m}\end{array}$ & $26.0 \pm 0.3^{*}$ & $18.0 \pm 0.3^{*}$ & $15.3 \pm 0.3^{*}$ & $21.4 \pm 0.4^{*}$ \\
\hline $\begin{array}{l}\text { Средний размер ядер, мкм } \\
\text { Nucleus average size, } \mu \mathrm{m}\end{array}$ & $6.7 \pm 0.07^{*}$ & $5.0 \pm 0.09^{*}$ & $4.6 \pm 0.1^{*}$ & $6.0 \pm 0.1^{*}$ \\
\hline
\end{tabular}

* Статистическая значимость различий по сравнению с предыдущими группами $p \leq 0.00$.

Statistical significance of difference in comparison with the previous groups $p \leq 0.00$.

ядер). Невысокая частота НФО в нашем исследовании сопоставима с результатами пересмотров опухолей щитовидной железы у детей, проведенных в медицинских центрах Европы и США [15].

При электронно-микроскопическом исследовании клетки ФВ ПК характеризовались утратой межклеточных контактов и десмосом, отсутствием полярности и микроворсинок в апикальной области. Ядра выглядели крупными, с конденсированным по краям кариолеммы гетерохроматином, ядрышко чаще единичное, иногда обнаруживались безъядерные клетки. В некоторых клетках опухоли идентифицированы ядерноцитоплазматические инвагинации (рис. 1, А). Цитоплазма скудная, вакуолизированная, с редукцией гранулярной эндоплазматической сети и слабо развитым пластинчатым комплексом (рис. 1, В). Подобные изменения указывают на высокую пролиферативную активность, а также на утрату специфических ультраструктурных признаков нейроэндокринных клеток. Признаки деструкции с разрушением внеклеточного матрикса, появлением клеток с пикнотичны- desintegration of extracellular matrix, the appearance of cells with pycnotic nuclei, sharp cytoplasm vacuolization and the appearance of mitochondria with cleared matrix were revealed rather often at the sites of the capillary wall invasion by tumor cells (Fig. 1, C). Much seldom cells of another type were met in the samples of papillary carcinoma: cell of smaller size, the nucleus was presented with euchromatin with the plenty of free ribosomes, mitochondria and the presence of secretory vacuoles (Fig. 1, D). Cellular pull heterogeneity in papillary carcinomas is explained in terms of differentiation rate and functional activity of tumor cells [16].

Ultrastructural polymorphism was also inherent in NFT cells with nuclei of papillary type. At the same time the communication between cells as chinked contacts in the basal part and desmosomes in the apical area were preserved, cell polarity was not broken; microvilli were directed to follicular cavity (Fig. 2, A). Nuclei were large, polymorphous and atypical with dispersed euchromatin (Fig. 2, B). There was well-developed laminar complex in cy- 


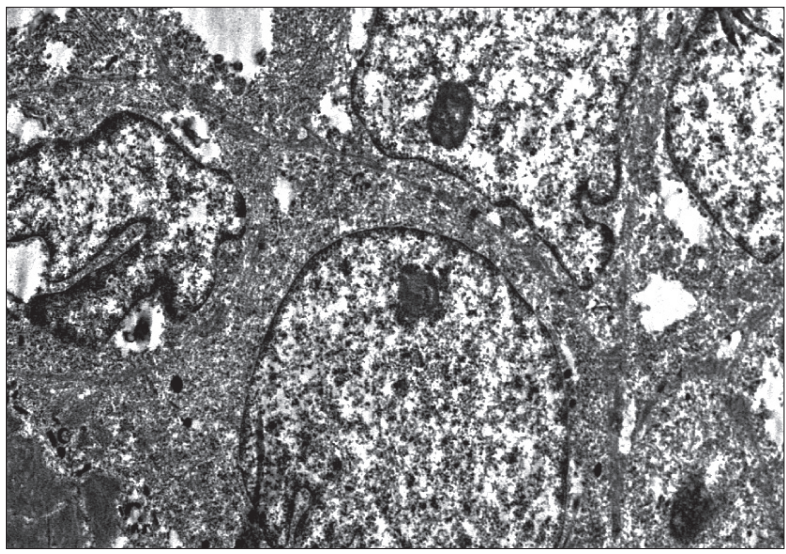

$\mathrm{C}$

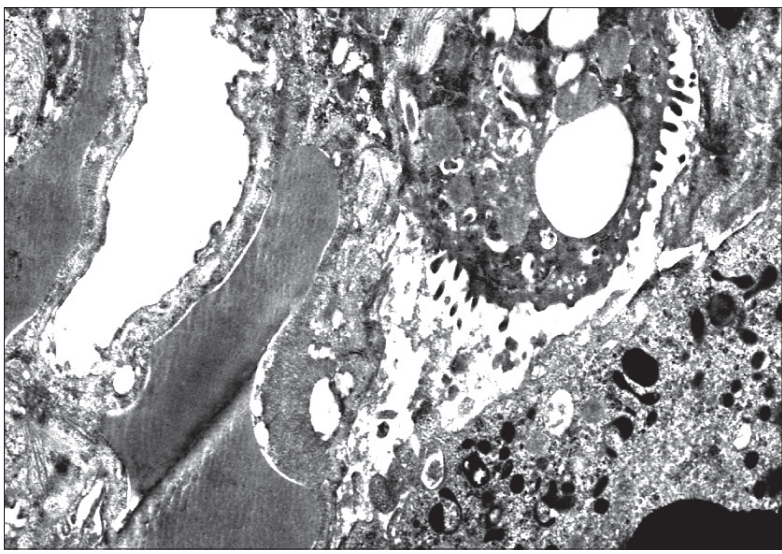

B

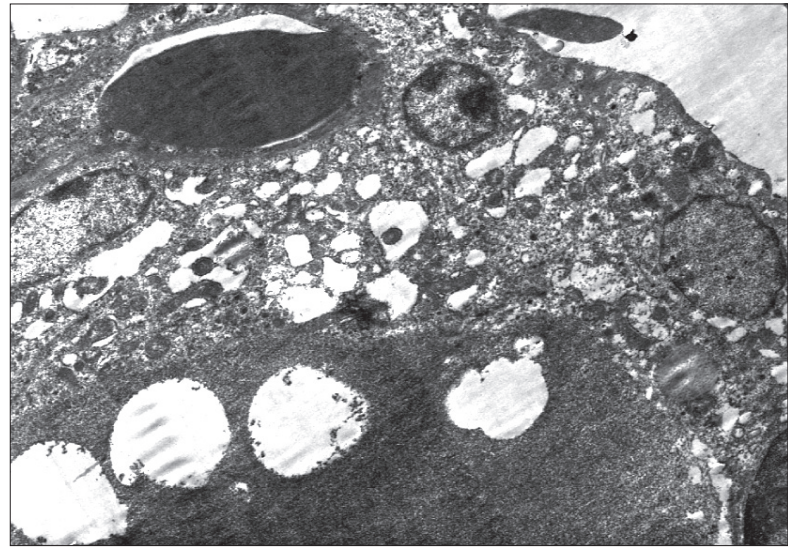

$\mathrm{D}$

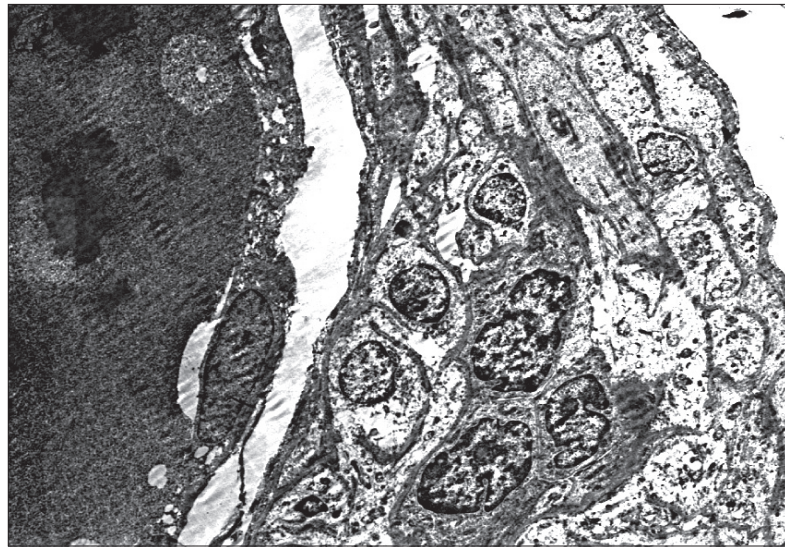

Рис. 1. Ультраструктурная характеристика папиллярного рака щитовидной железы:

А - ядра с инвагинациями, гетерохроматином, конденсированным под кариолеммой и в ядрышках (×7786); В - клетки с потерей полярности, микроворсинок, вакуолизацией цитоплазмы (×5190);

C - врастание опухолевой клетки в стенку капилляра (×9860); D - клетки разной степени дифференцировки, формирующие фолликул (×30о0)

Fig. 1. Ultrastructural characteristics of thyroid papillary cancer:

A - nuclei with invaginations, heterochromatin condensed under karyolemma and in nucleoli ( $\times 7786)$;

B - cells with loss of polarity, microvilli, cytoplasmic vacuolization $(\times 5190)$; $\mathrm{C}-$ growing of tumor cells into the capillary wall $(\times 9860)$; D - cells of different differentiation rate forming the follicle $(\times 3000)$

ми ядрами, резкой вакуолизацией цитоплазмы и появлением митохондрий с просветленным матриксом обнаруживались достаточно часто в местах инвазии стенок капилляров опухолевыми клетками (рис. 1, C). Намного реже в образцах папиллярной карциномы встречались клетки другого типа: меньшего размера, ядро представлено эухроматином, с обилием свободных рибосом, митохондрий и наличием секреторных вакуолей (рис. 1, D). Гетерогенность клеточного пула в папиллярных карциномах объясняется степенью дифференцировки и функциональной активности опухолевых клеток [16].

Ультраструктурный полиморфизм был присущ также клеткам НФО с ядрами папиллярного типа. При этом коммуникация между клетка- toplasm, endoplasmic reticulum was filled up with flaky contents, there were a lot of electronic-dense vesicles (Fig. 2, C, D). Such ultrastructural signs are the evidence of the conservation of organospecificity of tumor cells. Meanwhile, NFT thyrocytes with nuclei of papillary type distinguished by a larger nucleus, reduction and the shortening of microvilli, the increase number of mitochondria and the amount decrease of laminar complex as compared to the unaltered thyroid gland.

\section{CONCLUSION}

Thyroid neoplasms of follicular structure in children and adolescents are characterized by encapsulated growth of the singular node, frequent 
A

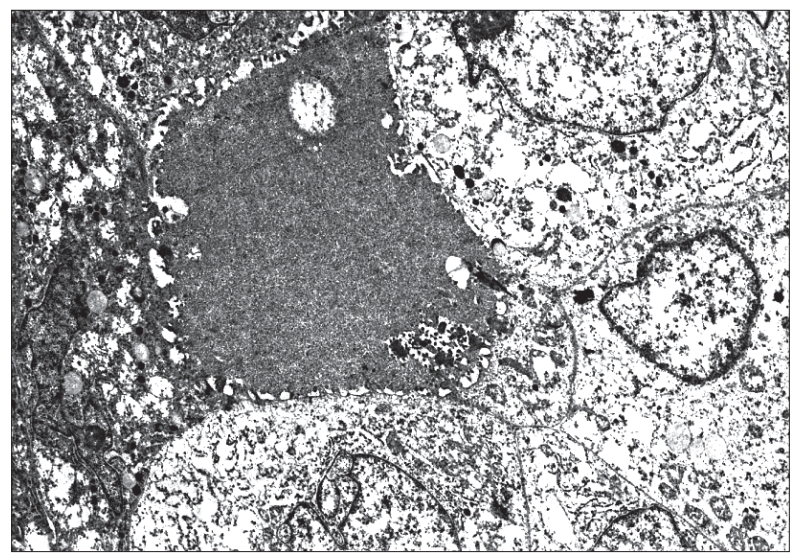

$\mathrm{C}$

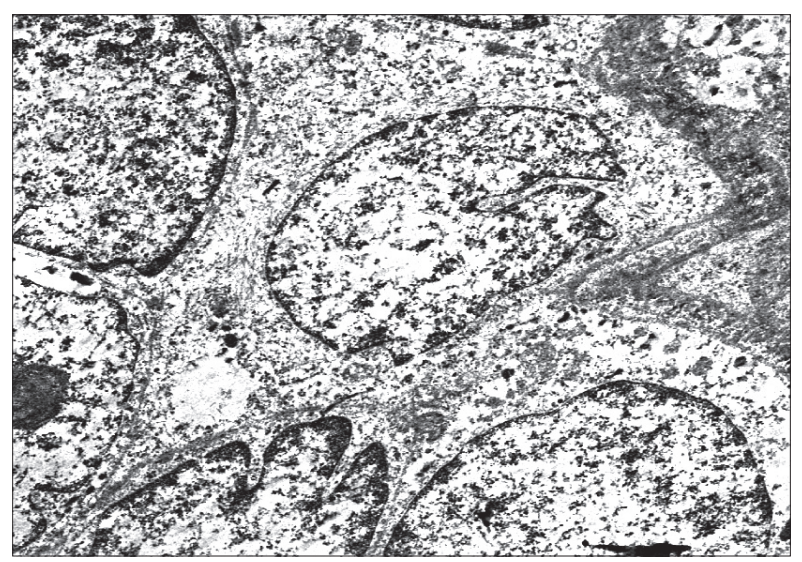

B

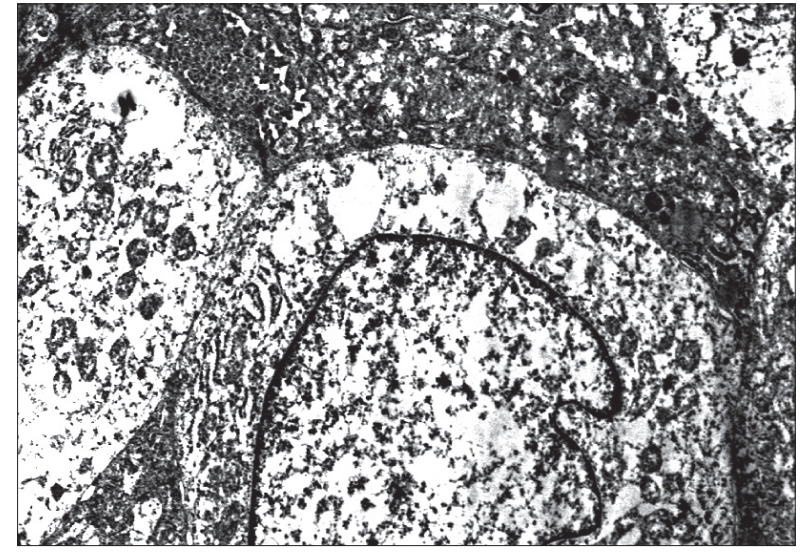

$\mathrm{D}$

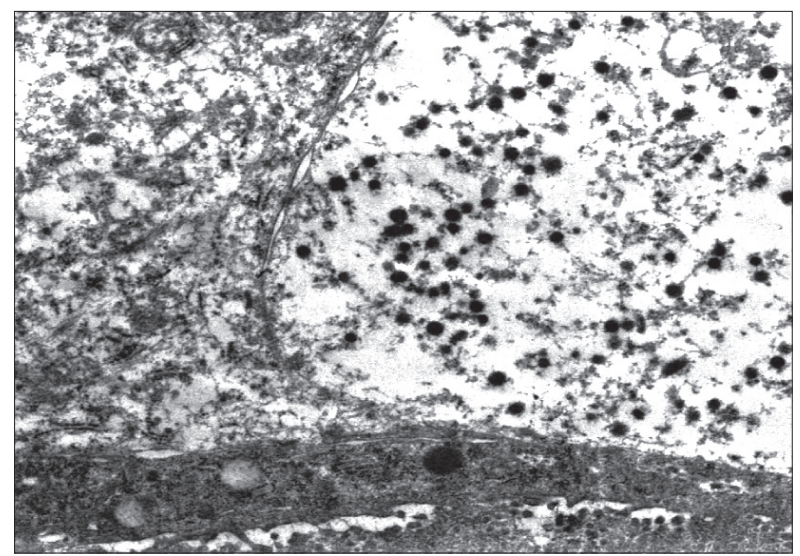

Рис. 2. Ультраструктурная характеристика неинвазивной фолликулярной опухоли щитовидной железы с ядрами папиллярного типа:

A - сохранение органоспецифичности в опухолевых клетках (×4820); В - укрупненные ядра с эухроматином, в цитоплазме много митохондрий, развита эндоплазматическая сеть (×7540); $\mathrm{C}-$ внутриядерные инвагинации и ядерные цитоплазматические включения (×8280); D - обилие электронно-плотных гранул, филаментов, сохранение щелевидных контактов и десмосом между клетками опухоли (×12 430)

Fig. 2. Ultrastructural characteristics of noninvasive follicular thyroid neoplasm with nuclei of papillary type: A - conservation of organospecificity in tumor cells $(\times 4820)$; B - enlarged nuclei with euchromatin, plenty of mitochondria in cytoplasm, developed endoplasmic reticulum $(\times 7540)$; $\mathrm{C}-$ intranuclear invaginations and nuclear cytoplasmic inclusions $(\times 8280)$; D - plenty of electron-dense granules, conservation of filaments, chunked contact and desmosomes between tumor cells ( $\times 12430)$

ми в виде щелевидных контактов в базальной части и десмосом в апикальной зоне сохранялась, полярность клеток не нарушена, микроворсинки обращены в полость фолликулов (рис. 2, А). Ядра крупные, полиморфные и атипичные, с диспергированным эухроматином (рис. 2, В). В цитоплазме хорошо развитый пластинчатый комплекс, эндоплазматическая сеть заполнена хлопьевидным содержимым, много электронно-плотных везикул (рис. 2, C, D). Такие ультраструктурные признаки свидетельствуют о сохранении органоспецифичности опухолевых клеток. Вместе с тем тиреоциты НФО с ядрами папиллярного типа отличались более крупным ядром, редукцией и укорочением микроворсинок, увеличением чис- combination with comorbid pathology, and carcinomas are defined with the absence of metastasis. The conducted study gives the evidence of low noninvasive follicular thyroid neoplasm with nuclei of papillary type rate in children and adolescents $-4 \%$ of cases. Peculiarities of benign and malignant neoplasms with nuclei papillary type are: smoothing of sexual differences, frequently combined with autoimmune diseases of the thyroid gland, the increase of karyometric parameters as compared with follicular adenomas and carcinomas. Ultrastructural analysis showed that tumor cells with nuclei of papillary type (FV PC, NFT) distinguish themselves by the pronounced polymorphism. At the same time, 
ла митохондрий и снижением объема пластинчатого комплекса по сравнению с неизмененной щитовидной железой.

\section{ЗАКЛЮЧЕНИЕ}

Опухоли щитовидной железы фолликулярного строения у детей и подростков характеризуются инкапсулированным ростом единичного узла, частым сочетанием с коморбидной патологией, а карциномы - отсутствием метастазов. Проведенное исследование свидетельствует о невысокой частоте у детей и подростков неинвазивной фолликулярной опухоли с ядрами папиллярного типа -4 \% случаев. Особенностями доброкачественных и злокачественных опухолей с ядрами папиллярного типа являются: сглаживание половых различий, частое сочетание с аутоиммунными заболеваниями щитовидной железы, увеличение кариометрических параметров по сравнению с фолликулярными аденомами и карциномами. Ультраструктурный анализ показал, что клетки опухолей с ядрами папилляр-

\section{СПИСОК ЛИТЕРАТУРЫ}

1. Хмельницкий О.К. Цитологическая и гистологическая диагностика заболеваний щитовидной железы. СПб.: СОТИС, 2002.

2. Абросимов А.Ю. Новая международная гистологическая классификация опухолей щитовидной железы // Архив патологии. 2018. Т. 80 (1). С. 37-45. doi: 10.17116/patol201880137-45.

3. Воробьев С.Л. Размышления патолога о цитологической диагностике неоплазий щитовидной железы // Архив патологии. 2011. Т. 73 (2). С. 57-61.

4. Казубская Т.П., Козлова В.М., Кондратьева Т.Т. и др. Фолликулярно-клеточный (папиллярный и фолликулярный) рак щитовидной железы, генетическая обусловленность и маркеры диагностики // Архив патологии. 2014. Т. 76 (5). С. 3-12.

5. Черствой Е.Д., Неровня А.М., Пожарская В.П. Некоторые аспекты иммуногистохимической и молекулярно-биологической характеристики папиллярного рака щитовидной железы у детей // Архив патологии. 1998. Т. 60 (2). С. 8-12.

6. Осипов С.В., Привалов В.А., Яйцев С.В. и др. Особенности клинического течения и отдаленные результаты хирургического лечения рака щитовидной железы у детей и подростков // Детская хирургия. 2002. № 4. С. 33-36.

7. Онищенко Г.Г. Чернобыль - 30 лет спустя. Радиационно-гигиенические и медицинские последствия аварии // Радиационная гигиена. 2016. Т. 9 (2). С. 10-19.

8. Фридман М. В., Маньковская С.В., Красько О.В., Демидчик Ю.Е. Сравнительный клинико-морфологический анализ «техногенного» и «криптогенного» папиллярного рака щитовидной железы у детей и подростков // Архив патологии. 2014. Т. 76 (5). C. 20-25. cells with signs of neuroendocrine differentiation prevail in a noninvasive follicular thyroid neoplasm with nuclei of papillary type in contrast to FV PC, in which cellular forms with the loss of secretory activity and organospecificity predominate.

Conflict of interest. The authors declare no conflict of interest.

ного типа (ФВ ПК и НФО) отличаются выраженным полиморфизмом. Вместе с тем в неинвазивной фолликулярной опухоли с ядрами папиллярного типа превалируют клетки с признаками нейроэндокринной дифференцировки в отличие от ФВ ПК, при котором преобладают клеточные формы с утратой секреторной активности и органоспецифичности.

Конфликт интересов. Авторы заявляют об отсутствии конфликта интересов.

\section{REFERENCES}

1. Khmelnitskiy O.K. (2002). Cytological and Histological Diagnostics of Thyroid Gland Diseases. St. Petersburg. In Russ.

2. Abrosimov A.Yu. (2018). The new international histological classification of thyroid tumors. Archive of Pathology, 80 (1), 37-45. doi: 10.17116/patol201880137-45.

3. Vorobyev S.L. (2011). A pathologist's thoughts on the cytological diagnosis of thyroid neoplasias. Archive of Pathology, 73 (2), 57-61.

4. Kazubskaya T.P., Kozlova V.M., Kondratyeva T.T. et al. (2014). Follicular cell (papillary and follicular) thyroid cancer, genetic causation and diagnostic markers. Archive of Pathology, 76 (5), 3-12. In Russ.

5. Cherstvoy E.D., Nerovnya A.M., Pozharskaya V.P. (1998). Certain aspects of immunohistochemical and molecular-biological characteristics of papillary thyroid cancer in children. Archive of Pathology, 60 (2), 8-12.

6. Osipov S.V., Privalov V.A., Yaytsev S.V. et al. (2002). Peculiarities of clinical course and follow-up results of the surgical treatment for thyroid cancer in children and adolescents. Russ. J. of Pediatric Surgery, $4,33-36$.

7. Onishchenko G.G. (2016). The Chernobyl - thirty years after the post-accidental radiological-hygienic and medical consequences. Radiation Hygiene, 9 (2), 10-19.

8. Fridman M.V., Man'kovskaia S.V., Kras'ko O.V., Demidchik Iu.E. (2014). Comparative clinical and morphological analysis of technogenic and cryptogenic papillary thyroid carcinoma in children and adolescents. Archive of Pathology, 76 (5), 20-25.

9. Baleva L.S., Yakovleva I.N., Karakhan N.M., Danilycheva L.I. (2013). Radiation-induced thyroid pathol- 
9. Балева Л.С., Яковлева И.Н., Карахан Н.М., Данилычева Л.И. Радиоиндуцированная патология щитовидной железы у лиц, подвергшихся воздействию радиации в результате аварии на ЧАЭС во внутриутробном, детском и подростковом возрасте // Рос. вестн. перинатологии и педиатрии. 2013. Т. 58 (5). C. $82-86$.

10. WHO Classification of Tumours of Endocrine Organs / Lloyd R.V., Osamura R.Y., Klöppel G., Rosai J. (eds.). Lyon: IARC, 2017.

11. Nikiforov Y., Seethale R.R., Zubair W.P. et al. Nomenclature revision for encapsulated follicular variant of papillary thyroid carcinoma // JAMA Oncol. 2016. Vol. 2 (8). P. 1023-1029.

12. Jug R., Jian X. Noninvasive follicular thyroid neoplasm with papillary-like nuclear features: an evidence-based nomenclature change // Patology Res. Int. 2017. Vol. 2017. 6 p. doi: 10.1155/2017/1057252.

13. Morris L.G.T., Sikora A.G., Tosteson T.D., Davies L. The increasing incidence of thyroid cancer: the influence of access to care // Thyroid. 2013. Vol. 23 (7). P. 885-891. doi: 10.1089/thy.2013.0045

14. Verburg A.F., Van Santen H.M., Luster M. Pediatric papillary thyroid cancer: current management challenges // Onco Targets Ther. 2016. No. 10. P. 165175. doi: 10.2147/OTT.S100512.

15. Rossi E.D., Mehrotra S., Kilic A.I. et al. Noninvasive follicular thyroid neoplasm with papillary-like nuclear features in the pediatric age group // Cancer Cytopathology. 2018. Vol. 126. P. 27-35.

16. Павлова Т.В., Смирнова Е.А., Гуревич Л.Е., Павлов И.А. Ультраструктурные и иммуногистохимические особенности рака щитовидной железы // Архив патологии. 2008. Т. 70 (4). С. 10-13.

\section{СВЕДЕНИЯ ОБ АВТОРАХ}

Пастернак Илона Анатольевна - канд. мед. наук, ассистент кафедры патологической анатомии и судебной медицины ФГБОУ ВО «Южно-Уральский государственный медицинский университет» Минздрава России (Челябинск).

Казачков Евгений Леонидович - д-р мед. наук, профессор, заведующий кафедрой патологической анатомии и судебной медицины ФГБОУ ВО «Южно-Уральский государственный медицинский университет» Минздрава России (Челябинск).

Пастернак Алексей Евгеньевич - канд. мед. наук, начальник ГБУЗ «Челябинское областное бюро судебно-медицинской экспертизы» Минздрава Челябинской области.

Образец цитирования: Пастернак И.А., Казачков Е.Л., Пастернак А.Е. Фолликулярно-клеточные опухоли щитовидной железы: клинические и морфологические особенности у детей и подростков // Journal of Siberian Medical Sciences. 2019. № 3. C. $15^{-23}$. ogy in persons exposed in utero, infancy, childhood, and adolescence to irradiation as a result of the Chernobyl accident. Russ. Bull. of Perinatology and Pediatrics, 58 (5), 82-86.

10. Lloyd R.V., Osamura R.Y., Klöppel G., Rosai J. (eds.) (2017). WHO Classification of Tumours of Endocrine Organs. Lyon: IARC.

11. Nikiforov Y.E., Seethala R.R., Tallini Z.W. et al. (2016). Nomenclature revision for encapsulated follicular variant of papillary thyroid carcinoma: a paradigm shift to reduce overtreatment of indolent tumors. JAMA Oncol., 2 (8), 1023-1029.

12. Jug R., Jiang X. (2017). Noninvasive follicular thyroid neoplasm with papillary-like nuclear features: an evidence-based nomenclature change. Patology Res. Int., 2017, 6 p. doi: 10.1155/2017/1057252.

13. Morris L.G., Sikora A.G., Tosteson T.D., Davies L. (2013). The increasing incidence of thyroid cancer: the influence of access to care. Thyroid, 23 (7), 885891. doi: 10.1089/thy.2013.0045.

14. Verburg F.A., Van Santen H.M., Luster M. (2016). Pediatric papillary thyroid cancer: current management challenges. Onco Targets Ther., 10, 165-175, doi: 10.2147/OTT.S100512.

15. Rossi E.D., Mehrotra S., Kilic A.I. et al. (2018). Noninvasive follicular thyroid neoplasm with papillarylike nuclear features in the pediatric age group. Cancer Cytopathol., 126, 27-35.

16. Pavlova T.V., Smirnova E.A., Gurevich L.E., Pavlov I.A. (2008). Ultrastructural and immunohistochemical features of thyroid cancer. Archive of Pathology, $70(4), 10-13$.

\section{ABOUT THE AUTHORS}

Pasternak Ilona Anatolyevna - Cand. Sci. (Med.), Assistant of the Pathologic Anatomy and Forensic Medicine Department, South Ural State Medical University (Chelyabinsk).

Kazachkov Evgeniy Leonidovich - Dr. Sci. (Med.), Professor, Head of the Pathologic Anatomy and Forensic Medicine Department, South Ural State Medical University (Chelyabinsk).

Pasternak Aleksey Evgenyevich - Cand. Sci. (Med.), Chief of Chelyabinsk Regional Office of Forensic Medical Examination.

Citation example: Pasternak I.A., Kazachkov E.L., Pasternak A.E. (2019). Follicular cell tumors of thyroid gland: clinical and morphological characteristics in children and adolescents. Journal of Siberian Medical Sciences, 3, 15-23. 